\title{
PARAMAGNETIC DEFECTS IN SILICON STRUCTURES WITH NANOCRYSTALLITES
}

\author{
V. Ya. Bratus' \\ Institute of Semiconductor Physics NASU, \\ 45 Nauky Pr., Kyiv, 03028, Ukraine
}

(Received December 19, 2002)

\begin{abstract}
A brief review of original electron paramagnetic resonance (EPR) and electron-nuclear double resonance (ENDOR) studies on some silicon-based structures with nanocrystallites is presented. The $P_{b}$ center in high-temperature annealed porous silicon has been investigated with ENDOR. High sensetivity of the ENDOR technique to hydrogen presence has been found. In Si-, Ge- and C-implanted layers of $\mathrm{SiO}_{2}$ and spark-processed silicon the distinct silicon- and oxygen-vacancy associated defects have been identified with EPR. The origin of the defects in spark-prosecced $\mathrm{Si}$ is discussed in detail. The resumblence and distinction of the defects in silicon-based matrices with nanocrystallites illustrate a variety of structural transformations there. The role of paramagnetic defects in photoluminescence is briefly discussed.

Key words: paramagnetic defect, nanocrystallite, Si-based structure, ion implantation, EPR, ENDOR.
\end{abstract}

PACS number(s): 61.46.+w, 68.35.Dv, 76.30.Mi, 76.70.Dx

\section{INTRODUCTION}

Silicon is the most widely used semiconductor material. Starting with the observation of a strong visible photoluminescence (PL) from Si layers with high porosity [1], there has been considerable research activity in the manufacturing of luminescent structures as well as in the understanding of the origin of various PL bands. A number of methods have been developed for preparation of Si nanocrystallites. Among them are the formation of porous silicon by electrochemical dissolution of monocrystalline Si, spark processing of Si, high dose ion implantation of $\mathrm{Si}$ or Ge atoms into the $\mathrm{SiO}_{2}$ matrix and $\mathrm{SiO}$ deposition onto various substrates by thermal evaporation in vacuum. With the exception of electrochemical etching, forming quantum wires covered with thin natural oxide, most of the methods produce semiconductor nanocrystallites embedded in semiconducting or dielectric matrix. The obtained compound can be a highly defective system, involving defects in nanocrystallites, covered matrix and their interface.

Various mechanisms have been proposed for the explanation of the origin of different luminescent bands, including quantum confinement and electron-hole recombination at $\mathrm{Si} / \mathrm{SiO}_{2}$ interface and defect states. In this respect the identification of the defects in luminescent $\mathrm{Si}_{-}$ based structures is of particular interest. Magnetic resonance techniques like electron paramagnetic resonance (EPR) and electron-nuclear double resonance (ENDOR) are the indispensable tools for identifying defects in crystalline and amorphous materials [2], they are well suited for a quantitative study of the volume and surface defects. The symmetry of defect wave function is reflected in the EPR spectrum through the $g$-tensor observed. The implementation of ENDOR technique, which has much higher resolution then EPR, allows to study details of hyperfine (HF) interaction originating from the diverse nuclei with non-zero spins and look into the surroundings of the unpaired spin of a defect.

A short review of previous and new original EPR and ENDOR investigations on the above-mentioned structures is presented in this paper. The role of paramagnetic defects in PL is briefly discussed.

\section{ENDOR STUDY OF THE $P_{b}$ CENTER IN POROUS SILICON}

The dangling bond of a silicon atom at the (111) $\mathrm{Si} / \mathrm{SiO}_{2}$ interface, called the $P_{b}$ center, is the dominant paramagnetic defect in porous silicon [3]. Initially, its model was suggested from the observed orientation of the symmetry axis of $g$-tensor and HF tensor along the $<111>$ directions of the silicon substrate. It is denoted as $\bullet \mathrm{Si} \mathrm{Si}_{3}$, where the dot symbolizes the unpaired electron. After the identification of this defect a set of EPR studies has been performed in order to determine the spatial distribution of the $P_{b}$ centers and the extended microscopic structure of them in the oxide at the interface. The use of ENDOR technique was unfeasible for $\mathrm{Si} / \mathrm{SiO}_{2}$ interface defects associated with thermal oxides on silicon owing to a small number of them $\left(\leq 1.3 \times 10^{13} \mathrm{~cm}^{-2}\right)$. Extremely high surface areas (up to $600 \mathrm{~m}^{2} / \mathrm{cm}^{3}$ ) of porous silicon samples enable to observe intense EPR lines even at room temperature. The EPR analysis has revealed the preservation of crystallinity in the remaining Si skeleton even for high porosity luminescent structures [3].

At first, two featureless broad lines at the Larmor frequencies $\nu_{\mathrm{L}}$ of ${ }^{1} \mathrm{H}$ and ${ }^{19} \mathrm{~F}$ nuclei were observed in the ENDOR spectrum [4]. They were attributed to hydrogen and fluorine atoms passivating dangling bonds which locate at some distance from the $P_{b}$ center. It was not astonishing since it is well known that bonded hydro- 
gen atoms are always present in thermally oxidized and porous silicon in the form of $\mathrm{SiH}, \mathrm{SiH}_{2}$ and $\mathrm{SiOH}$ species. An appearance of fluorine atoms in porous Si from the electrolyte was also awaited.

With high porosity free-standing samples and optimized conditions for ENDOR detection a new set of lines, named the $N$-spectrum, near the Larmor frequency of ${ }^{1} \mathrm{H}$ was revealed (Fig. 1a). The observation of an angular dependence of the $N$-spectrum is the unambiguous evidence that hydrogen nuclei can occupy certain distinct positions in the vicinity of the $P_{b}$ center [5]. So, residing at near paramagnetic defect, a proton can serve as a probe to elucidate the defect structure. We have examined the "extended" Poindexter's model previously used for analysis of dipolar interaction between $P_{b}$ defects [6] and found its validity. In this model (111) Si plane at the interface is unreconstructed and Si sites form two-dimensional triangular net of lattice parameter $a_{L}=$ $3.84 \AA$. It is suggested that the $P_{b}$ centers are randomly distributed over the net.

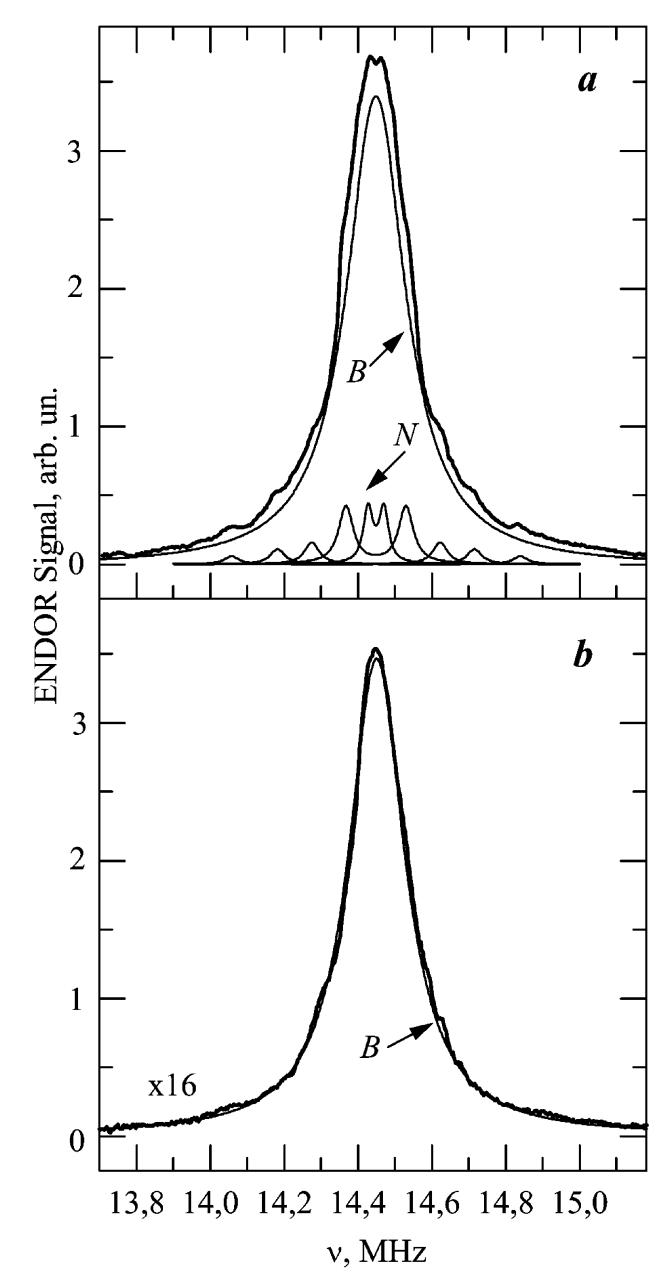

Fig. 1. The ${ }^{1} \mathrm{H}$ ENDOR spectrum of the $P_{b}$ center in porous $\mathrm{Si}$ (solid lines) at $4.2 \mathrm{~K}$ and its computer simulation (thin lines) for as-prepared $(a)$ and annealed in high vacuum at $850^{\circ} \mathrm{C}$ for $30 \mathrm{~min}(b)$ samples. The orientation of the magnetic field $\mathbf{H} \|<001\rangle$, the Larmor frequency of ${ }^{1} \mathrm{H}$ is at 14.44 $\mathrm{MHz}$.
Interesting ENDOR results have been obtained on high vacuum annealed samples of porous Si. After the annealing at $400^{\circ} \mathrm{C}$, the concentration of the $P_{b}$ centers is increased about one order of magnitude, the ENDOR signal is also enhanced and the $N$-spectrum is still observed. After subsequent annealing at $550^{\circ} \mathrm{C}$, when, according to Ref. [7], hydrogen moves off from the SiH species, the ENDOR signal is decreased significantly and it is necessary to use higher microwave and radiofrequency power $\left(\mathrm{P}_{\mathrm{mv}} \approx 50 \mu \mathrm{W}\right.$ and $\left.\mathrm{H}_{\mathrm{rf}}>1.2 \mathrm{G}\right)$. Under such conditions the $N$-spectrum is beyond detectability even on the best free-standing samples (Fig. 1b). Notice that after the annealing of porous $\mathrm{Si}$ at $450^{\circ} \mathrm{C}$ an additional isotropic line characterized by $g \approx 2.006$ and peak-to-peak linewidth of $8 \mathrm{G}$ becomes dominant. This line, probably, is related to the disoriented $P_{b}$ centers. Nevertheless, in spite of the ENDOR signal decrease, the lineshape of the broad line $B$ leaves unchanged for the samples annealed up to $865^{\circ} \mathrm{C}$. It is not improbable that the hydrogen remainder belongs to $\mathrm{O}-\mathrm{H}$ bonds that are more stable than $\mathrm{Si}-\mathrm{H}$ bonds. In any case, this study demonstrates high sensitivity of the ENDOR technique to hydrogen presence in porous Si.

It is known that non-radiative recombination centers such as $P_{b}$ have a strong influence on the PL efficiency. However, no simple correlation between them has been found in highly porous layers of various doping levels $[8$, $9]$.

\section{LIGHT-EMITTING Ge-IMPLANTED $\mathrm{SiO}_{2}$ LAYERS}

Implantation of Si, Ge and $\mathrm{C}$ ions into silicon oxide followed by thermal annealing is a promising technique for the formation of nanocrystallites in $\mathrm{SiO}_{2}$. An important advantage of this technique is tight control over the concentration and distribution profile of the implanted atoms, and its full compatibility with silicon technology.

Likewise $\mathrm{Si}^{+}$and $\mathrm{C}^{+}$studies $[10,11]$, the experiments with implantation of $\mathrm{Ge}^{+}$ions were performed with 600 $\mathrm{nm} \mathrm{SiO}_{2}$ films grown on a $p$-type (100)Si substrate. To create the "box" profile, the $\mathrm{SiO}_{2}$ matrix was implanted with $\mathrm{Ge}^{+}$ions of a set of energies $E_{1}=20 \mathrm{keV}$, $E_{2}=50 \mathrm{keV}, E_{3}=100 \mathrm{keV}, E_{4}=150 \mathrm{keV}$ and total dose of $3 \times 10^{16} \mathrm{~cm}^{-2}$. The implantation-induced defects in $\mathrm{SiO}_{2}$ layer like $E_{\gamma}^{\prime}$ and non-bridging oxygen hole centers $(N B O H C)$ [12], denoted as $\bullet \mathrm{O}-\mathrm{Si} \equiv$, have been detected by EPR for both Ge and Si implants (Fig. 2a). The model for an oxygen-vacancy associated $E^{\prime}$ center has been established as an unpaired electron spin occupying a dangling $s p^{3}$ hybrid orbital of a silicon bonded to only three oxygen. It can be denoted as $\bullet \mathrm{Si} \equiv \mathrm{O}_{3}$. The distinctive feature of the same dose $\mathrm{Si}^{+}$-implanted $\mathrm{SiO}_{2}$ is an occurrence of the EPB and EP4 defects of the $E^{\prime}$ family and a broad line with $g \approx 2.0020$ at a zero crossing (Fig. $2 b$ ) which can be attributed to the Si dangling bond $(D B)$ point defects in off-stoichiometric regions of $\mathrm{SiO}_{2}[10]$. 

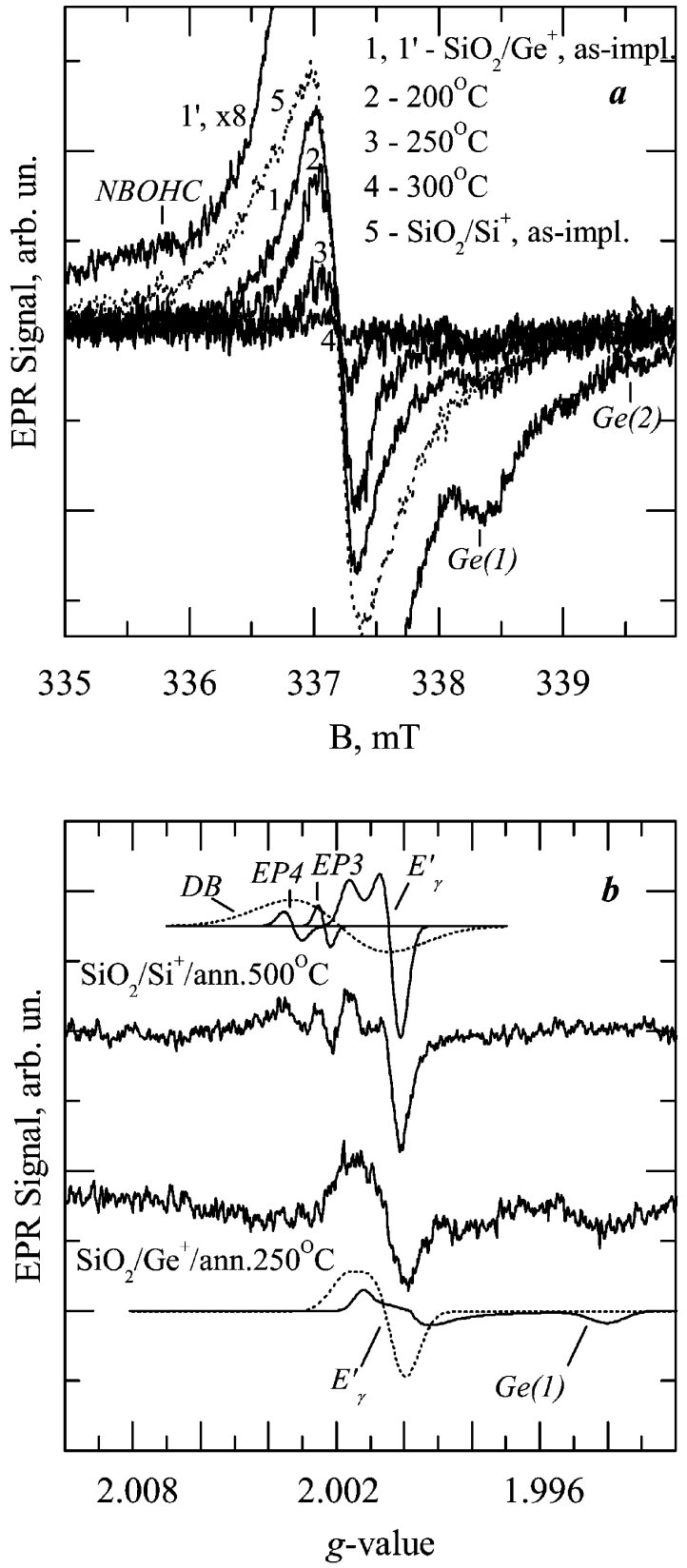

Fig. 2. Room temperature EPR spectra of defects induced by implantation of the $\mathrm{Ge}^{+}$and $\mathrm{Si}^{+}$ions with a dose of $3 \times 10^{16} \mathrm{~cm}^{-2}$ into $\mathrm{SiO}_{2}$ layers: $a$ - before and following thermal annealing at certain temperature for $15 \mathrm{~min} ; b-$ simulation of certain of the spectra, where a $\Delta g=0.0004$ distribution was introduced for $g_{2}$ and $g_{3}$ values to simulate the spectrum of the Ge(1) center. All experimental spectra were detected with the same spectrometer settings.

In addition, the Ge(1) (with principal $g$ values of $g_{1}=2.0008, g_{2}=1.9994$ and $\left.g_{3}=1.9931\right)$ and $\mathrm{Ge}(2)$ $\left(g_{1}=2.0010, g_{2}=1.9978, g_{3}=1.9868\right)$ defects have been revealed for the first time in $\mathrm{Ge}^{+}$-implanted layers. Previously, similar EPR lines were observed in Ge-doped silica-core optical fiber and in $\mathrm{SiO}_{2}$ as well as in $\mathrm{GeO}_{2}$ glasses [13]. Tentatively, they were assigned to an elec- tron trapped at the site of an oxygen vacancy in a $s p^{3}$ orbital of Ge atom which is coordinated through bridging oxygens to one, Ge(1), or two, Ge(2), next-nearest neighbor germanium atoms. The observed Ge-centers in unannealed samples could occur if considerable part of germanium ions substituted for silicons after the dissipation of their energy in the $\mathrm{SiO}_{2}$ layer. Similary to $\gamma$-irradiated Ge-doped silica-core optical fiber [13], the intensity of the $\mathrm{Ge}(0)$ and $\mathrm{Ge}(3)$ spectra in Ge-implanted $\mathrm{SiO}_{2}$ samples is negligible compared to the Ge(1) and Ge(2) ones. The relative intensity of the latters is about four in the unannealed samples. Due to its small intensity, the Ge(2) spectrum is not observed even after annealing at $200^{\circ} \mathrm{C}$, while the $E_{\gamma}^{\prime}$ defect bleaches more readly than the Ge(1) center (Fig. 2b).

It should be pointed out that contrary to Si-implanted samples any distinct EPR lines with $g \geq 2.0025$ have not been found after annealing at moderate temperatures of Ge-implanted (Fig. 2b) as well as Ar- and Ne-implanted $\mathrm{SiO}_{2}$ layers [10]. This implies that EP2, EP3 and EP4 defects are related to the regions of silicon oxide supersaturated with silicon atoms.

No detectable EPR spectra have been recorded in $\mathrm{Ge}^{+}$- and $\mathrm{Si}^{+}$-implanted $\mathrm{SiO}_{2}$ samples after annealing at $T>700^{\circ} \mathrm{C}$ for $15 \mathrm{~min}$. Another situation occurs in $\mathrm{C}^{+}$-implanted and co-implanted $\mathrm{SiO}_{2}$, where EPR lines with $g=2.0025$ are detected even after annealing at $1200^{\circ} \mathrm{C}$ for 1 hour [11]. The same stability against annealing and identical EPR spectrum has been observed in amorphous carbon films. Thus the EPR results give an additional evidence in farour of the formation of carbon or/and carbon-rich nanocrystallites in $\mathrm{SiO}_{2}$. Contrary to $\mathrm{Ge}^{+}-$and $\mathrm{Si}^{+}$-implanted $\mathrm{SiO}_{2}$ samples, the appearance of features at $g \approx 2.002$ and $g \approx 2.008$ being characteristic of the $P_{b}$ centers were observed on the $\mathrm{SiO}_{x}$ layer formed after $\mathrm{SiO}$ deposition onto various substrates by thermal vacuum evaporation [14]. As follows from the EPR and Raman spectra, the coagulation of Si atoms in this case leads to the formation of their amorphous phase at $T_{\text {ann. }}=900^{\circ} \mathrm{C}$. According to Raman data, subsequent raise of the annealing temperature to $1100^{\circ} \mathrm{C}$ leads to the formation of Si nanocrystallites. So the features appearing in the EPR spectra can be attributed to the defects of nanocrystalline- $\mathrm{Si} / \mathrm{SiO}_{2}$ interface.

The correlation between changes in EPR and PL band peaked at $650 \mathrm{~nm}$ arrives at the conclusion that this band is associated with defects or complexes of defects [14].

\section{DEFECTS IN SPARK-PROCESSED Si}

After the discovery of visible PL from porous silicon it was demonstrated that spark erosion of crystalline $\mathrm{Si}$ in air or in different gas atmosphere yields similar PL spectra [15]. The stability of this PL towards degradation upon ultraviolet radiation was found to be extremely high. According to the transmission electron microscopy and electron diffraction studies the spark-processed silicon (sp-Si) contains the islands of silicon nanocrystallites of various orientations and sizes embedded in amorphous 
$\mathrm{SiO}_{2}$ matrix. The sizes of the individual nanocrystallites, which have a polycrystalline nature, range from $4 \mathrm{~nm}$ to $125 \mathrm{~nm}$. It was suggested that the presence of nanocrystalline structures is responsible for the visible PL of spSi. Optical and structural properties were studied in a succession of works and overviewed in Ref. [16]. The first detection of the EPR spectrum in sp-Si was reported [17] but none of the defects was identified.

The samples under study were prepared by spark processing of $n$-type (111)Si having As concentration of $2 \times 10^{19} \mathrm{~cm}^{-3}$ and $400 \mu \mathrm{m}$ thickness. Unipolar high voltage $(15 \mathrm{kV})$ pulses were applied between a tungsten tip (anode) and a silicon substrate (cathode). The repetition frequency was determined by the voltage source and was set to be $16 \mathrm{kHz}$. Below the tungsten tip, which was separated by $1 \mathrm{~mm}$ gap from the Si wafer, the spark process creates circular patterns on the Si surface. After spark processing for $1 \mathrm{~h}$, a lateral diameter of about $3 \mathrm{~mm}$ and maximum depth of about $200 \mu \mathrm{m}$ in the center were reached. Two sets of samples were studied, sparkprocessed under stagnant air conditions for $0.5 \mathrm{~h}$ and $1 \mathrm{~h}$ and under flowing air conditions for $0.5 \mathrm{~h}, 1 \mathrm{~h}$ and $2 \mathrm{~h}$. Some of sp-Si samples were thermally annealed for $15 \mathrm{~min}$ in nitrogen ambient at temperatures ranging from $200^{\circ} \mathrm{C}$ to $1100^{\circ} \mathrm{C}$.

Fig. 3 shows the EPR spectra of the sp-Si samples measured at $300 \mathrm{~K}$. A superposition of a broad line, labeled $W$, with a zero crossing at $g=2.0037$ and a narrow line with $g$-values in the range of $2.0020-1.9999$ is observed for all the samples studied. The latter range is typical for the family of $E^{\prime}$ center [12]. A separation of $E^{\prime}$ line from the net spectrum and analysis of its shape has shown that this line can be depicted by $g$-values of the $E_{\gamma}^{\prime}$ center $\left(g_{1}=2.0017, g_{2}=2.0006, g_{3}=2.0002\right)$ with distribution of $g_{2}$ and $g_{3}$ values. In the case of sp-Si structures it has been this $g$-value distribution which has led to a considerable broadening of the $E^{\prime}$ line as well as $W$ line in the Q-band. With continuous-wave microwave saturation measurements it has been found that $E^{\prime}$ line starts to saturate at power level of $0.4 \mathrm{~mW}$. The $W$ line is about 10 times less saturable in terms of microwave power then $E^{\prime}$ line.

Both relative intensity of these lines and volumetric density of defects are determined by processing conditions. The total density of defects for the Si wafers processed in stagnant air is less than that processed in flowing air. The prolongation of the processing time in stagnant air from $0.5 \mathrm{~h}$ to $1 \mathrm{~h}$ reduces defect density from $7.2 \times 10^{17} \mathrm{~cm}^{-3}$ to $2.1 \times 10^{17} \mathrm{~cm}^{-3}$. While for the samples processed in the flowing air we have found $2.6 \times 10^{18}$ $\mathrm{cm}^{-3}, 4.0 \times 10^{18} \mathrm{~cm}^{-3}$ and $2.5 \times 10^{18} \mathrm{~cm}^{-3}$ defects for $0.5 \mathrm{~h}, 1 \mathrm{~h}$ and $2 \mathrm{~h}$ duration, respectively. The range of $g$-values, an inherent feature at $g=2.0020$ of hightemperature annealed sample and its very high thermal stability are good direct evidences to attribute this defect to the $P_{b}$ center.

Several weak EPR lines can be observed in sp-Si at a higher gain (Fig. 3a). A weak pair of lines labeled $H$ with a $7.42 \mathrm{mT}$ separation are disposed at equal distance on either side of the $E^{\prime}$ central resonance. According to the studies of the "bulk" $\mathrm{SiO}_{2}$, the defect with $7.4 \mathrm{mT}$ doublet structure was reasonably assigned to a hydrogen coupled $E^{\prime}$ center [18]. Due to the model, a proton is located in the immediate neighborhood of the $E^{\prime}$ center forming a $\bullet \mathrm{Si} \equiv \mathrm{O}_{2} \mathrm{H}$ defect. Notice that it is the first evidence of hydrogen inclusion into sp-Si, FTIR spectra have not revealed any of $\mathrm{Si}-\mathrm{H}$ species there.
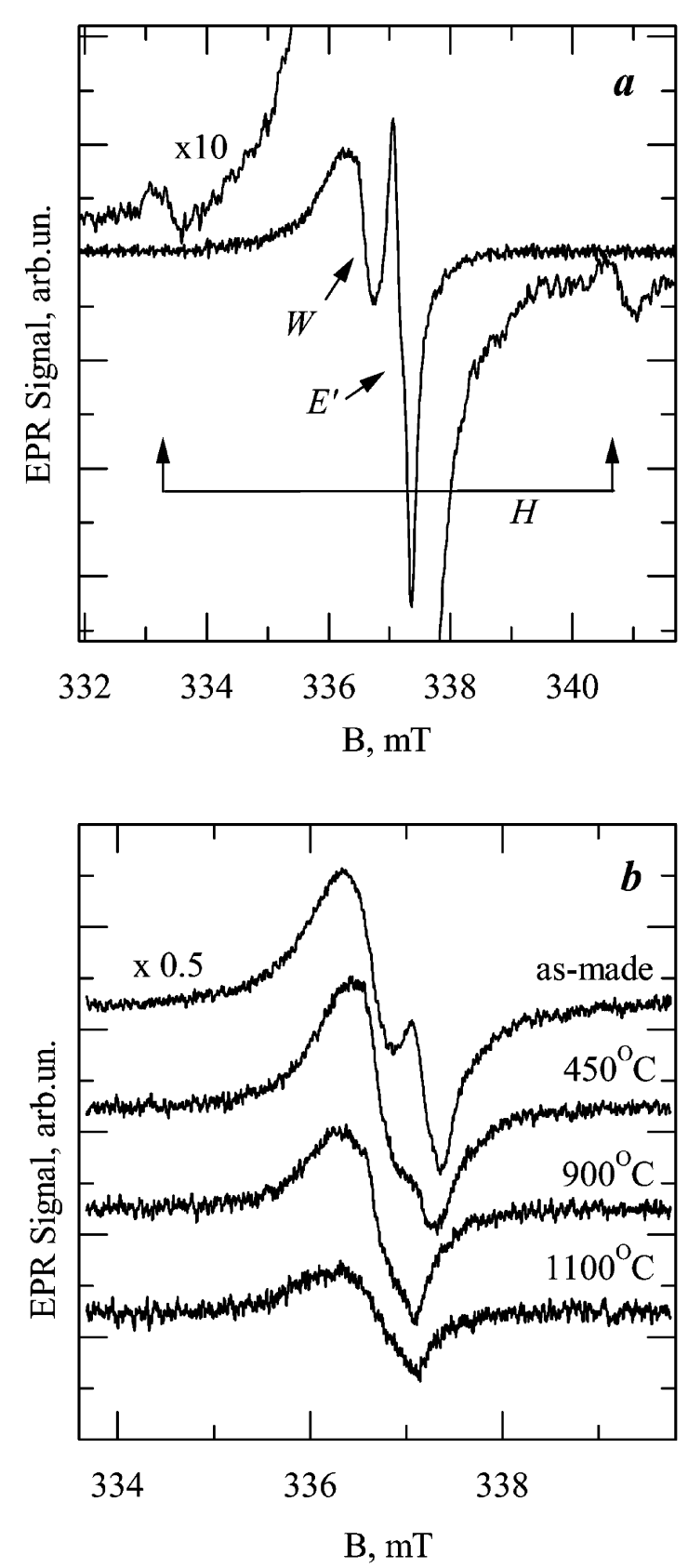

Fig. 3. Room temperature EPR spectra of the unannealed Si wafer spark-processed under flowing air for 1 hour $(a)$ and 0.5 hour successively annealed at temperature ranging from $200^{\circ} \mathrm{C}$ to $1100^{\circ} \mathrm{C}$ for $15 \min (b)$.

Isochronal thermal anneal of sp-Si structures shows that the $E^{\prime}$ line disappears after annealing at $700^{\circ} \mathrm{C}$ 
while the $W$ line is extremely stable (Fig. $3 b$ ). The $W$ line separated from the $E^{\prime}$ spectrum has a typical powder-like shape with $g=2.0044$ at a zero crossing and the $g$-values of 2.0065 and 2.0020 at the extreme points. According to the simulation, the EPR spectrum of sp-Si samples annealed at $T_{\text {ann }} \geq 700^{\circ} \mathrm{C}$ can be represented as a superposition of a symmetric Gaussian line with $g=2.0044$ and $\Delta B_{p p}=0.67 \mathrm{mT}$ and a powder shape of the $P_{b}$ center response $\left(g_{\|}=2.0020, g_{\perp}=2.0086\right)$. The contribution of the first line is dominant and the origin of this line is of prime interest. According to the literature sources, the $E P \mathscr{Z}$ center has smaller width possessing $g=2.0045$ at a zero crossing and is not observed after the annealing of $\mathrm{Si}^{+}$-implanted $\mathrm{Si} / \mathrm{SiO}_{2}$ structures at $T_{\text {ann }} \geq 600^{\circ} \mathrm{C}$ [10]. Slightly asymmetric EPR line with the $g$-value of 2.0043 and $\Delta B_{p p} \approx 1.0 \mathrm{mT}$ has been observed in quasione-dimensional $a-\mathrm{Si}: \mathrm{H}$ [19]. This line was assigned to defects in polysilane $\left(\mathrm{SiH}_{2}\right)_{n}$ structure whose backbone consists entirely of silicon atoms. An isotropic EPR signal at $g=2.0045$ and $\Delta B_{p p} \approx 0.8 \mathrm{mT}$ was observed at $4.2 \mathrm{~K}$ in native-oxidized freshly prepared porous silicon samples [20], attributed to the amorphous $\mathrm{SiO}$ center. A center identical to this has been detected in Si-rich oxide powder [20]. We believe that the formation of both Sirich oxide and quasi-one-dimensional silicon structures is highly probable during the spark processing of silicon. So they seem to be major contributors to the response with $g=2.0044$.

A correlation between the number of paramagnetic defects with $g=2.0044$ and PL intensity of $576 \mathrm{~nm}$ band has been found, indicating the defect origin of the latter.

\section{CONCLUSION}

As a conclusion of this study, the identification and understanding of the role of defects allow to clarify the nature of processes taking place in silicon structures with nanocrystallites. The detection of various species of paramagnetic defects illustrates the multiformity and considerable complexity of the structural transformations there. The EPR combined with optical measurements is a powerful technique for identifying the structure of both nanocrystallites and matrix where they are embedded as well as interface region.

The author would like to thank Prof. H. J. von Bardeleben, Prof. P. L. F. Hemment, Prof. R. E. Hummel and Prof. M. Ya. Valakh for supply of samples and numerous helpful discussions.
[1] L. T. Canham, Appl. Phys. Lett. 57, 1046 (1990).

[2] J.-M. Spaeth, J. R. Niklas, R. H. Bartram, Structural Analysis of Point Defects in Solid (Springer-Verlag, Berlin Heidelberg, 1992).

[3] H. J. von Bardeleben, D. Stievenard, A. Grosman, C. Ortega, J. Siejeka, Phys. Rev. B 47, 10899 (1993).

[4] V. Ya Bratus', S. S. Ishchenko, S. M. Okulov, I. P. Vorona, H. J. von Bardeleben, M. Schoisswohl, Phys. Rev. B 50, 15449 (1994).

[5] V. Ya. Bratus', S. S. Ishchenko, S. M. Okulov, I. P. Vorona, H. J. von Bardeleben, Mater. Sci. Forum 196-201, 529 (1995).

[6] G. van Gorp, A. Stesmans, Phys. Rev. B 45, 4344 (1992).

[7] P. Gupta, V. L. Colvin, S. M. George, Phys. Rev. B 37, 8234 (1988).

[8] M. Schoisswohl, H. J. von Bardeleben, V. Bratus', H. Munder. Thin Solid Films 225, 163 (1995).

[9] H. J. von Bardeleben, M. Chamarro, A. Grosman, V. Morazzani, C. Ortega, J. Siejeka, S. Rigo, J. Lumin. 57, 39 (1993).

[10] M. Ya. Valakh, V. A. Yukhimchuk, V. Ya. Bratus', A. A. Konchits, P. L. F. Hemment, T. Komoda, J. Appl. Phys. 85, 168 (1999).
[11] M. Ya. Valakh, V. A. Yukhimchuk, V. Ya. Bratus', E. G. Gule, Ukr. Fiz. Zh. 46, 1065 (2001).

[12] D. L. Griscom, E. J. Friebele, Phys. Rev. B 34, 7524 (1986).

[13] E. J. Friebele, D. L. Griscom, G. H. Sigel, Jr., J. Appl. Phys. 45, 3424 (1974).

[14] V. Ya. Bratus', V. A. Yukhimchuk, L. I. Berezhinsky, M. Ya. Valakh, I. P. Vorona, I. Z. Indutnyi, T. T. Petrenko, P. E. Shepeliavyi, I. B. Yanchuk, Semiconductors 35, 821 (2001).

[15] R. E. Hummel, S.-S. Chang, Appl. Phys. Lett. 61, 1965 (1992).

[16] M. H. Ludwig, in Handbook of Optical Properties, V. II: Optics of Small Particles and Surfaces, (CRC Press, 1996).

[17] J. Hack, M. H. Ludwig, W. Geerts, R. E. Hummel, Mater. Res. Soc. Symp. Proc. 452, 147 (1997).

[18] T. E. Tsai, D. L. Griscom, J. Non-Cryst. Solids 91, 170 (1987).

[19] S. Nanomura, S. Hattori, H. Hayashi, T. Itoh, S. Nitta, J. Non-Cryst. Solids 114, 729 (1989).

[20] C. F. Young, E. H. Poindexter, G. J. Gerardi, J. Appl. Phys. 81, 7468 (1997). 


\title{
ПАРАМАГНЕТНІ ДЕФЕКТИ У КРЕМНІЙОВИХ СТРУКТУРАХ 3 НАНОКРИСТАЛІТАМИ
}

\author{
В. Я. Братусь \\ Інститут фізики напієпровідників Націоналъной академї̈ наук Украйни, \\ просп. Науки, 45, Киӥ, Озо28, Украйна \\ E-mail:endor@div51.semicond.kiev.ua
}

\begin{abstract}
Подано короткий огляд дослідження кремнійових структур із нанокристалітами із застосуванням методів електронного парамагнетного резонансу (ЕПР) та подвійного електронно-ядерного резонансу (ПЕЯР). Методом ПЕЯР вивчали $\mathrm{P}_{b}$-центри в пористому кремнії, який було відпалено при високій температурі. Виявлено високу чутливість ПЕЯР до наявности водню. У шарах $\mathrm{SiO}_{2}$, імплантованих йонами $\mathrm{Si}$, Ge та С, та в еродованому іскрою кремнії методом ЕПР визначено окремі дефекти, пов'язані з вакансіями кремнію та кисню. Докладно обмірковано природу дефектів в еродованому іскрою кремнії. Подібність та ві,дмінність дефектів у матрицях на основі кремнію з нанокристалітами демонструє розмаїття структурних перетворень у них. Стисло обговорено роль парамагнетних дефектів у фотолюмінесценції.
\end{abstract}

